\title{
Distribution of VOCs between air and snow at the Jungfraujoch high alpine research station, Switzerland, during CLACE 5 (winter 2006)
}

\author{
E. Starokozhev ${ }^{1}$, E. Fries ${ }^{2}$, A. Cycura ${ }^{3}$, and W. Püttmann ${ }^{1}$ \\ ${ }^{1}$ Institute of Atmospheric and Environmental Sciences, Department of Analytical Environmental Chemistry, \\ J. W. Goethe-University Frankfurt/Main, Frankfurt/Main, Germany \\ ${ }^{2}$ Institute of Environmental Systems Research, University Osnabrück, Osnabrück, Germany \\ ${ }^{3}$ Environment Monitoring Center, Orenburg State University, Orenburg, Russia
}

Received: 10 June 2008 - Published in Atmos. Chem. Phys. Discuss.: 25 July 2008

Revised: 14 April 2009 - Accepted: 1 May 2009 - Published: 15 May 2009

\begin{abstract}
Volatile organic compounds (VOCs) were analyzed in air and snow samples at the Jungfraujoch high alpine research station in Switzerland as part of CLACE 5 (CLoud and Aerosol Characterization Experiment) during February/March 2006. The fluxes of individual compounds in ambient air were calculated from gas phase concentrations and wind speed. The highest concentrations and flux values were observed for the aromatic hydrocarbons benzene (14.3 $\left.\mu \mathrm{g} \cdot \mathrm{m}^{-2} \mathrm{~s}^{-1}\right)$, 1,3,5-trimethylbenzene $\left(5.27 \mu \mathrm{g} . \mathrm{m}^{-2} \mathrm{~s}^{-1}\right)$, toluene $\left(4.40 \mu \mathrm{g} \cdot \mathrm{m}^{-2} \mathrm{~s}^{-1}\right)$, and the aliphatic hydrocarbons i-butane $\left(7.87 \mu \mathrm{g} . \mathrm{m}^{-2} \mathrm{~s}^{-1}\right)$, ipentane $\left(3.61 \mu \mathrm{g} \cdot \mathrm{m}^{-2} \mathrm{~s}^{-1}\right)$ and n-butane $\left(3.23 \mu \mathrm{g} \cdot \mathrm{m}^{-2} \mathrm{~s}^{-1}\right)$. The measured concentrations and fluxes were used to calculate the efficiency of removal of VOCs by snow, which is defined as difference between the initial and final concentration/flux values of compounds before and after wet deposition. The removal efficiency was calculated at $-24^{\circ} \mathrm{C}$ $\left(-13.7^{\circ} \mathrm{C}\right)$ and ranged from $37 \%(35 \%)$ for o-xylene to $93 \%$ (63\%) for i-pentane. The distribution coefficients of VOCs between the air and snow phases were derived from published poly-parameter linear free energy relationship (ppLFER) data, and compared with distribution coefficients obtained from the simultaneous measurements of VOC concentrations in air and snow at Jungfraujoch. The coefficients calculated from pp-LFER exceeded those values measured in the present study, which indicates more efficient snow scavenging of the VOCs investigated than suggested by theoretical predictions.
\end{abstract}

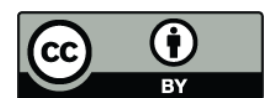

Correspondence to: E. Starokozhev (starokozhev@iau.uni-frankfurt.de)

\section{Introduction}

Large quantities of a number of organic compounds enter the troposphere from a variety of sources. Some of these occur naturally, but most air pollutants are derived from human activities (anthropogenic) and can significantly change or impact the earth's natural life processes (Bidleman, 2001). Volatile organic compounds (VOCs) such as benzene, toluene, ethylbenzene and xylenes constitute an important group of anthropogenic organic compounds from combustion (vehicles, aircraft and fossil fuel power plants), fuel storage and transport, solvent usage and production, industrial emissions, landfills and hazardous waste facilities (Zalel et al., 2008). Some VOCs are toxic (e.g. benzene, 1,3-butadiene) and many are ozone precursors (Dollard et al., 2007). VOCs are transformed and removed from the troposphere by chemical processes including photolysis, reaction with hydroxyl $(\mathrm{OH})$ or nitrate $\left(\mathrm{NO}_{3}\right)$ radicals, and reaction with $\mathrm{O}_{3}$ (National Research Council, 1991; Atkinson et. al., 2006). It is well established that benzene and the alkylated benzenes react almost exclusively with $\mathrm{OH}$ radicals under the conditions prevalent in the lower troposphere (Atkinson et al., 2006). Secondary aerosol particles are formed from some organic compounds including toluene and pinenes (Odum et al., 1997; Kavouras et al., 1998; Kleindienst et al., 2004). As gases ( $\mathrm{Li}$ et al., 2005) and adsorbed on particles, some organic compounds (e.g. i-alkanes, aromatic hydrocarbons) can be transported over long distances from source regions to higher layers of the troposphere, where they can persist for long periods of time (Gröllert and Puxbaum, 2000; Fuzzi et al., 2006).

Published by Copernicus Publications on behalf of the European Geosciences Union. 


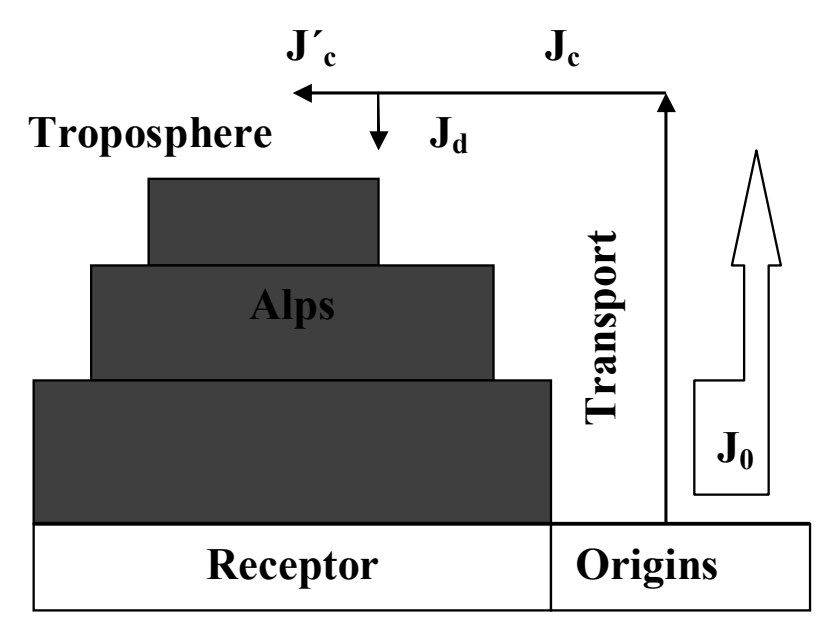

Fig. 1. Physico-chemical transport model of organic compounds in the troposphere.

The difference in atmospheric lifetimes of VOCs with respect to $\mathrm{OH}$ removal can be a useful tool to estimate the amount of photochemical processing in an advection flow (Monod et al., 2001). Other processes influencing the distribution pattern of VOCs are emission rates, mixing processes, dilution, and dry and wet deposition. At high latitudes and altitudes, such deposition of VOCs is greatly influenced by low temperatures and in particular the phase transition of water at temperatures below $0^{\circ} \mathrm{C}$ (Lei and Wania, 2004). In the atmosphere at high altitudes, snow and ice represent an important compartment for storage and reactions of environmentally relevant chemicals. Research has been conducted aimed at understanding the processes linked to the occurrence of organic pollutants in snow and ice since organic pollutants were detected in snow in remote areas and at a high alpine site (Roth et al., 2004; Gröllert and Puxbaum, 2000).

Here we present the results of measurements of selected VOCs in ambient air at the Jungfraujoch high alpine research station during field work associated with CLACE 5 (CLoud and Aerosol Characterization Experiment), undertaken in February/March 2006. In this paper, we investigate quantitative characteristics of VOCs distribution between atmospheric gas/snow phases during precipitation formation at Jungfraujoch.

\section{Background theory}

High alpine sites are appropriate locations to determine background concentrations of VOCs in the free troposphere, since these locations are primarily influenced by the long range transport of ozone and its precursors (Zanis et al., 2000). However, the concentrations of air contaminants (e.g. VOCs and aerosol particles) at higher altitudes $(>3000 \mathrm{~m}$ ) have also been shown to be affected by polluted regions in alpine val- leys (Prévot et al., 2000; Baltensperger et al., 1997a). Due to economic growth in Europe and construction of roads and tunnels in alpine regions, traffic and hence VOC emissions have increased markedly during the last decades, and are expected to increase further in the future (Prévot et al., 2000; Karl et al., 2001).

The environmental fate of VOCs is highly dependent on their partitioning in the atmosphere between gas and condensed phases like aerosols, rain, fog and snow. Such sorption processes can slow the long range transport of compounds in the atmosphere. A good understanding of the thermodynamic partition equilibria of organic pollutants is therefore the basis for a good understanding of their fate (Goss, 2004).

The atmosphere of the Swiss Alps is a multicomponent and multiphase system, and water can be present in all three states of aggregation under climate conditions. The organic vapors are present in the atmosphere in insufficient amounts to generate own phases. They can sorb onto solid or liquid surfaces and form surface films from which substances exchange into all phases. To determine the distribution of organic substances between different phases of the system, it is necessary to assess the contribution of processes involving the dispersion and transformation of compounds in ambient air, and their physical and chemical removal from the system. These processes are the transport of organic chemicals, their reactions with other compounds of the atmosphere $(\mathrm{OH}$ radicals, ozone, gaseous nitrogen oxides), and wet and dry deposition (Forrer et al., 2000).

In the Alps, the transport of organic compounds from emission sources to higher altitudes in the troposphere is a complex process consisting of several stages: the elevation (vertical transport) of the contaminants from the sources to the upper troposphere, the horizontal transport of the compounds in the upper troposphere, precipitation scavenging of organic chemicals, and their deposition on alpine surfaces (Fig. 1).

Especially the vertical mixing in a mountainous area is difficult to be described by any model. Air masses can reach the Jungfraujoch by the uphill wind and thermal advection from areas in the surrounding valleys. The source of these air masses is possibly the industrialized area, e.g. the Rhône valley in the south of Jungfraujoch or the Po Valley in the northern Italy.

On the slopes of the Alps, the thermal uplift of air masses usually takes place every day, except during particular weather conditions, e.g. foehn events. The influence of thermal uplift leads to the typical diurnal variations of VOC concentrations at Jungfraujoch described previously by Li et al. (2005).

Any transported compound can be quantitatively described by its fluxes, following the procedure described by Dämmgen et al. (1997). The vertical flux $\left(J_{0}\right)$ is directly proportional to the gradient of concentration of the substance 
$\left({ }_{\Delta} \mathrm{C}\right)$ between a source and a receptor (Eq. 1):

$J_{0} \approx_{\Delta} C$

The horizontal flux $\left(J_{c}\right)$ is described by convection, and is proportional to the concentration and velocity of the substance in the air flow (Eq. 2):

$J_{c} \approx C_{\text {air }} \cdot v$

where $C_{\text {air }}$ is the concentration of VOC in the air $\left(\mu \mathrm{g} . \mathrm{m}^{-3}\right)$ and $v$ is the velocity of the horizontal flux $\left(\mathrm{m} . \mathrm{s}^{-1}\right)$.

The flux of deposition $\left(J_{d}\right)$ is difficult to describe quantitatively. Hydrocarbons distribute among the different compartments of the multiphase atmospheric system (gas phase, aqueous droplets, aerosol particles, ice, and snow crystals). Their partitioning depends upon their nature and concentration, and on meteorological conditions. The deposition flux can be described by the density (d) and intensity (I) of precipitation (Eq. 3):

$J_{d} \approx I \cdot d$

Since mixing is diffusion-controlled, the system is considered to be in dynamic equilibrium. The partitioning of organic substances between the gas and other phases can be described by the distribution coefficient (Eq. 4), which contains characteristics of compound fluxes in the atmosphere as their equilibrium concentrations in the phases:

$K_{\text {air } / \text { snow }}=\frac{C_{\text {air }}}{C_{\text {snow }}}$

where $C_{\text {snow }}$ is the concentration of VOC in the precipitation (ng L $\left.{ }^{-1}\right)$.

The distribution of VOCs between the atmospheric phases determines whether and how the chemicals will be scavenged by precipitation (Lei and Wania, 2004). The partitioning constant varies among different compounds, which allows assessment of the major trends for processes relevant to each substance. When $K_{\text {air/snow }}$ approaches infinity, the efficiency of the scavenging process of organic compounds by precipitation is low. On the other hand, active precipitation scavenging of the compound will take place when $K_{\text {air/snow }}$ approaches 0 .

\section{Experimental section}

\subsection{Location and meteorology}

The large scale topography of the Swiss Alps is along a NW-SE cross section which is characterized by two mountain ranges divided by the deep Rhone Valley. The Jungfraujoch observation station on the Sphinx " platform ( $3580 \mathrm{~m}$ a.s.1., $46.55^{\circ} \mathrm{N}, 7.98^{\circ} \mathrm{E}$ ) is situated on the northerly crest on a mountain saddle between the mountains Jungfrau
(4158 $\mathrm{m}$ a.s.1.) in the west and Moench (4099 $\mathrm{m}$ a.s.1.) in the east (Fig. 2). During autumn, winter and spring, the research station is in the free troposphere in-cloud conditions about $40 \%$ of the time, whereas there is a clear influence from the planetary boundary layer in summer (Baltensperger et al., 1997a; Zanis et al., 2000). Meteorological processes on different spatial and time scales are important in the interpretation of trace gas observations at high alpine sites during the whole year (Forrer et al., 2000). These processes may contribute to the export of anthropogenic pollution from the boundary layer to the free troposphere. Meteorological information including air temperature, wind direction, wind speed, relative humidity and global radiation during sampling was obtained from the automatic meteorological station of the Swiss Meteorological Institute located also on the Sphinx' platform.

\subsection{Analytical methods}

Hydrocarbons were measured by a GC-FID automatic sampling instrument (AirmoVOC HC2010) with an integration time of $60 \mathrm{~min}$. The system was located in a laboratory at the top of the research station. The inlet of the GC system was a $1 / 8^{\prime \prime}$ stainless steel tube drawing outside air at $100 \mathrm{ml} \mathrm{min}^{-1}$ from $5 \mathrm{~m}$ above the bottom. The air sample was pre-concentrated at room temperature in an adsorption tube packed with two adsorbents $(3 \mathrm{~cm}$ Carbotrap B, $1 \mathrm{~cm}$ Carbosieve). The trapped components were desorbed by heating the adsorption tube to $250^{\circ} \mathrm{C}$ for $2 \mathrm{~min}$, then transported by $\mathrm{H}_{2}$ (5.0) to a cryofocusing unit. This unit consisted of a fused silica capillary tube packed with Carbopack and Envicarb X (2:1), which adsorbs hydrocarbons by $\mathrm{CO}_{2}$ cooling at $-45^{\circ} \mathrm{C}$. After heating of the cryotrap to $350^{\circ} \mathrm{C}$, the organic compounds were injected into a fused silica capillary column $(24 \mathrm{~m} \times 0.25 \mathrm{~mm}$, BGB 2.5; film thickness $1 \mu \mathrm{m}$, stationary phase $2.5 \%$ phenylpolysiloxane and $97.5 \%$ methylpolysiloxane) for chromatographic separation. In operation, the temperature program for the chromatographic separation starts at $30^{\circ} \mathrm{C}$, remains isothermal for $8 \mathrm{~min}$, then rises up to $150^{\circ} \mathrm{C}$ at a rate of $11^{\circ} \mathrm{C}$ per min and remains isothermal at $150^{\circ} \mathrm{C}$ for the last $3 \mathrm{~min}$. Flame ionization detection (FID) was used for quantitative analysis of organic trace compounds. Calibration of the system was performed with a thirty-component mixture produced and certified by NPL (National Physics Laboratory, UK). Hydrocarbons were identified based on their retention times. Accuracy values comprised the 2 sigma errors of calibration, the reproducibility of the measurements, and peak integration errors due to peak overlap and baseline noise. The detection limit was between 1 and $10 \mathrm{ppt}$, depending on the individual hydrocarbon. The precision of the instrument was $15 \%$ and the accuracy $10 \%$ for $\mathrm{C} 5-\mathrm{C} 9$, as found in several intercomparison campaigns for VOC measurements (Winkler, 2002).

Snow/ice was sampled during precipitation events using a custom built stainless steel collector installed on the Sphinx' 


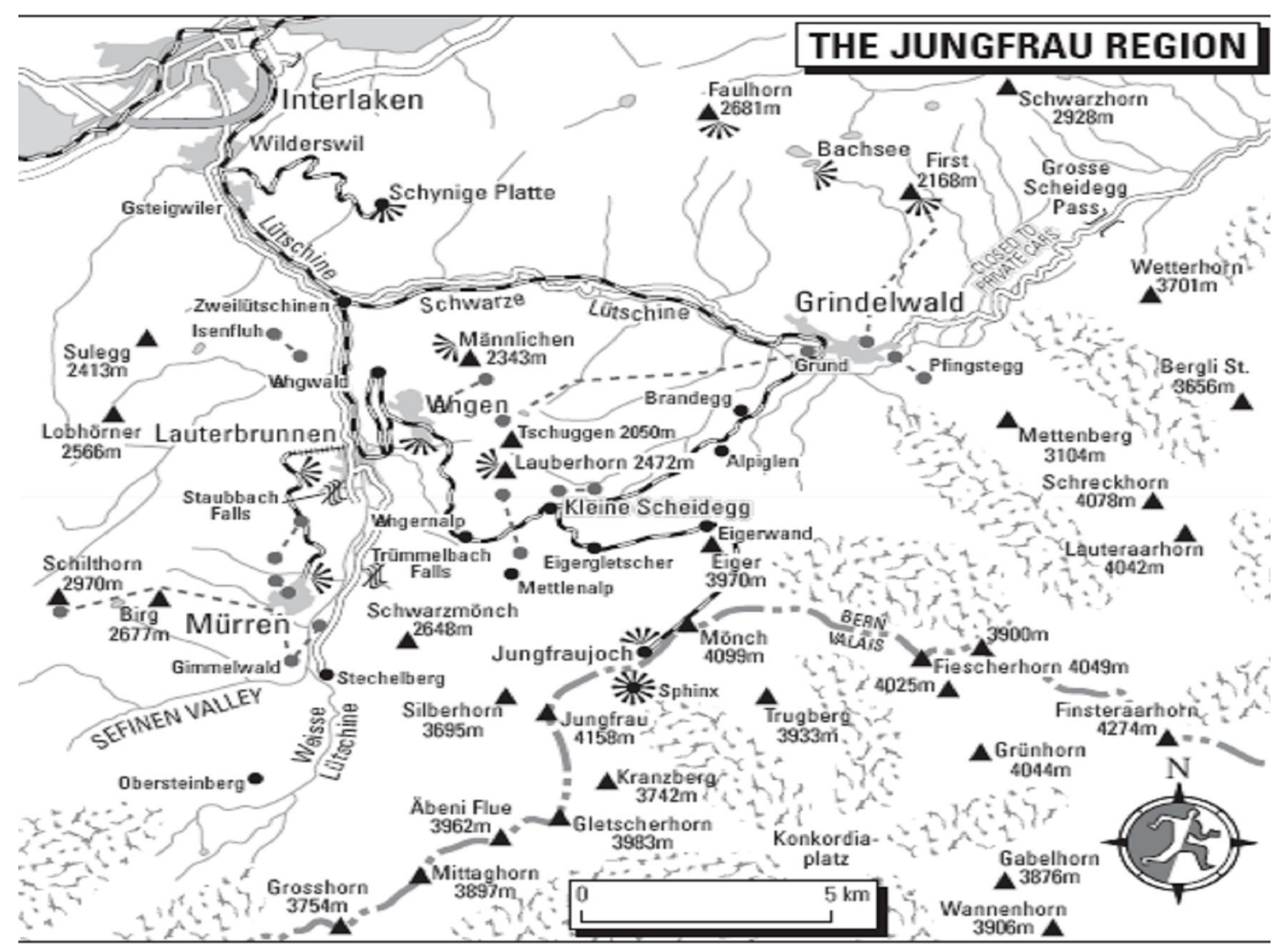

Fig. 2. Geographical setting of the Jungfraujoch high alpine research station, Switzerland (Rough Guides/Map published on http: //Switzerland.isyours.com).

platform at the research station. A total of 27 snow/ice samples were collected from 20-26 February and 1-5 March 2006. Analysis of VOC in melted snow samples was performed by HS-SPDE (headspace solid phase dynamic extraction) and GC/MS (gas chromatography/mass spectrometry). The relative standard deviations varied between 5 and $15 \%$ for benzene and the alkylated benzenes. The sampling procedures, and the HS-SPDE and GC/MS analytical methods have been described in detail by Fries et al. (2008) and Sieg et al. (2008).

\section{Results and discussion}

\subsection{VOC fluxes}

To assess the influence of atmospheric transformation of organic compounds on their further behavior, it is necessary to consider the atmosphere as a thermodynamic system; this requires simultaneous investigation and comparison of the meteorological and physico-chemical parameters of the system. The following meteorological parameters simultaneously reflect the thermodynamic characteristics of the atmosphere: (i) temperature describes the conditions of gas and vapor components in the atmosphere, (ii) wind speed describes transport of compounds in the ambient air, (iii) relative humidity gives the concentration of water vapor in the air and allows prediction of the direction of condensation and evaporation processes in the system at any moment, and (iv) global radiation provides a measure of the additional energy influencing the degree of condensation and evaporation of water and organic compounds in the air.

The concentrations of organic substances in the gas phase and snow were selected as physico-chemical parameters of the system.

Alkanes, alkenes and aromatic hydrocarbons were determined in the air samples during CLACE 5 (Fig. 3, Table 3). Data from four days of measurements were selected for investigation of the VOC distribution between the air and snow phases. Only on two of these days (24 February and 1 March) significant snowfall took place. The two other days (11 and 12 March) were clear and sunny. The air temperature on the selected days was always far below $0^{\circ} \mathrm{C}$, and varied from $-12^{\circ} \mathrm{C}$ (24 February and $\left.11 \mathrm{March}\right)$ to $-27^{\circ} \mathrm{C}$ ( 1 and 12 March). In order to assess the distribution of hydrocarbons between air/snow phases and their removal efficiency from air the system states before and after wet deposition can be 

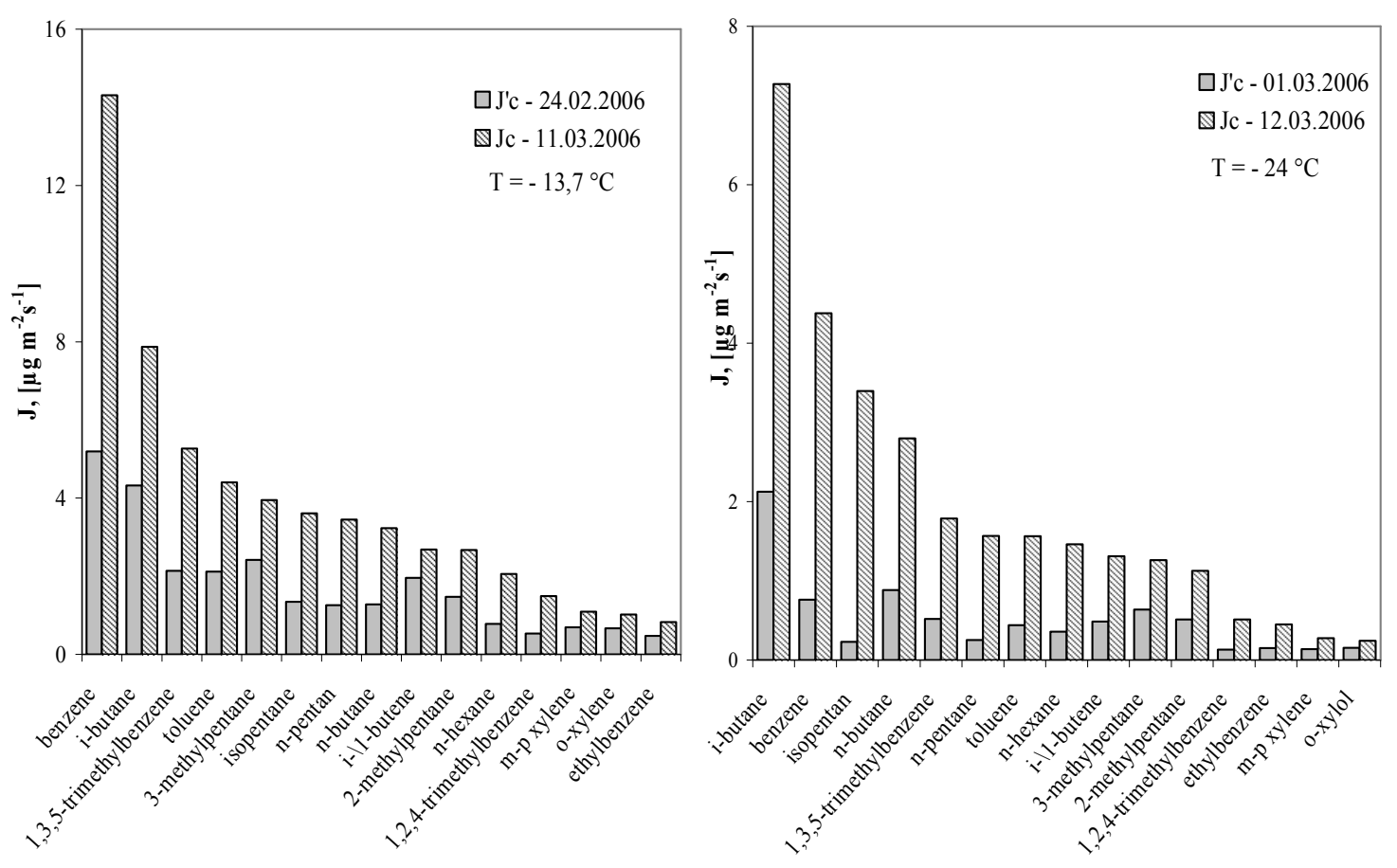

Fig. 3. Initial $\left(J_{c}\right)$ and final $\left(J^{\prime}{ }_{c}\right)$ fluxes (before and after wet deposition) of VOCs in the ambient air at temperatures below $0^{\circ} \mathrm{C}$ during CLACE 5 (2006).

compared. However, apart from snow scavenging also other factors (e.g. photochemical oxidation, temperature, humidity) can influence hydrocarbon concentrations in the atmosphere and affect dynamic equilibrium of VOC removal by snow. If the influence of these factors is constant before and after scavenging, these effects can be neglected in quantitative determination of the scavenging efficiency. This is the case when the thermodynamic conditions of the atmosphere are similar before and after snow scavenging. The thermodynamic regimes in the atmosphere (air temperature, relative humidity and global radiation) during the 16:00-20:00 time period on 24 February and 11 March and during the 08:00 to 12:00 time period on 1 and 12 March were the same (Table 1). Thus, it is possible to consider the atmospheric conditions on 11 and 12 March during the above-mentioned periods as the initial state of the thermodynamic system "atmosphere", and the conditions on the 24 February and 1 March as the final state of this system after the reaction (snow scavenging) took place.

Table 3 shows the concentrations of individual hydrocarbons measured in air samples during the selected time periods. The highest values of the aromatic and aliphatic hydrocarbons (in $\mu \mathrm{g} . \mathrm{m}^{-3}$ ) were found in the ambient air on 11 (12) March: benzene 1.1 (0.65), 1,3,5-trimethylbenzene 0.41 (0.27), toluene 0.34 (0.22), i-butane 0.61 (1.08), i-pentane 0.25 (0.51), and n-butane 0.27 (0.42). By far lower concentrations were determined for the following hydrocarbons on the same dates: 1,2,4-trimethylbenzene $0.12(0.077), \mathrm{m} / \mathrm{p}$ - xylene 0.08 (0.04), o-xylene 0.08 (0.036), ethylbenzene 0.06 (0.06). The concentrations of most hydrocarbons (see Table 3) were higher on 11 March than on 12 March, which could be explained by diurnal variations of the pollutants. According to Li et al. (2005) the enhancement of hydrocarbon concentrations, caused by thermal uplift, starts at midday and reaches peak concentrations in the late afternoon while during sampling in the morning low concentrations of hydrocarbons were found at Jungfraujoch. The results of $\mathrm{Li}$ et al. (2005) are in good agreement with results from the present study showing high concentrations of most VOCs during sampling in the afternoon on 11 March and low concentrations during sampling in the morning on 12 March. However, some aliphatic hydrocarbons (n-butane, i-butane, n-pentane, i-pentane) provided higher concentrations on 12 March in the morning than on 11 March in the afternoon. A conclusive reason for this unexpected observation is not available. The final concentrations $\left(\mathrm{C}^{\prime}\right)$ of VOCs after snow scavenging (on 24 February and 1 March) were for all hydrocarbons lower than their initial concentrations (C) before removal by snow (on 11 and 12 March).

Evaluation of the experimental data such as wind speed $\left(2-14 \mathrm{~m} \mathrm{~s}^{-1}\right)$, temperature, relative humidity, aerosol particle concentration during these days indicates a permanent transfer of the air mass in the atmosphere, forced by advection and convection and the existence of a non-equilibrium state of the atmosphere (as thermodynamic system). Thus, the concentration of organic substances in the atmosphere 
Table 1. Meteorological parameters during CLACE 5 (2006).

\begin{tabular}{|c|c|c|c|c|c|}
\hline Date & Sampling time & $\begin{array}{l}\text { Wind speed (vector) } \\
{\left[\mathrm{m} \mathrm{s}^{-1}\right]}\end{array}$ & $\begin{array}{l}\text { Relative } \\
\text { humidity [\%] }\end{array}$ & $\begin{array}{l}\text { Air temperature } \\
{\left[{ }^{\circ} \mathrm{C}\right]}\end{array}$ & $\begin{array}{l}\text { Global radiation } \\
{\left[\mathrm{W} \mathrm{m}^{-2}\right]}\end{array}$ \\
\hline \multirow{6}{*}{24 February } & 00:00-04:00 & 3.7 & 55.4 & -16.4 & 0 \\
\hline & 04:00-08:00 & 9.1 & 52.7 & -16.5 & 0 \\
\hline & 08:00-12:00 & 9.6 & 98.2 & -14.5 & 102 \\
\hline & $12: 00-16: 00$ & 14.2 & 98.5 & -13.7 & 312 \\
\hline & $16: 00-20: 00$ & 11.7 & 99.8 & -13.7 & 78 \\
\hline & $20: 00-24: 00$ & 15.7 & 99.3 & -14.2 & 0 \\
\hline \multirow{6}{*}{1 March } & $00: 00-04: 00$ & 8.1 & 100 & -21.6 & 0 \\
\hline & 04:00-08:00 & 7.9 & 97.5 & -22.5 & 0 \\
\hline & $08: 00-12: 00$ & 6.9 & 100 & -24.1 & 114 \\
\hline & $12: 00-16: 00$ & 4.2 & 98.7 & -23.2 & 390 \\
\hline & $16: 00-20: 00$ & 2.7 & 78.8 & -23.7 & 42 \\
\hline & $20: 00-24: 00$ & 2.9 & 52.8 & -24.4 & 0 \\
\hline \multirow{6}{*}{11 March } & $00: 00-04: 00$ & 5.1 & 96.3 & -17.8 & 0 \\
\hline & 04:00-08:00 & 7.5 & 99.3 & -17.8 & 0 \\
\hline & 08:00-12:00 & 8.2 & 98.3 & -18.3 & 126 \\
\hline & $12: 00-16: 00$ & 12.6 & 95.8 & -17.7 & 516 \\
\hline & $16: 00-20: 00$ & 13.3 & 99.8 & -13.7 & 78 \\
\hline & $20: 00-24: 00$ & 8.1 & 99.3 & -16.2 & 0 \\
\hline \multirow{6}{*}{12 March } & $00: 00-04: 00$ & 7.5 & 100 & -21.6 & 0 \\
\hline & 04:00-08:00 & 6.5 & 99.8 & -23.7 & 0 \\
\hline & $08: 00-12: 00$ & 6.7 & 100 & -24.3 & 114 \\
\hline & $12: 00-16: 00$ & 5.6 & 100 & -26.6 & 618 \\
\hline & $16: 00-20: 00$ & 5.6 & 99.1 & -27.6 & 102 \\
\hline & $20: 00-24: 00$ & 2.1 & 46.6 & -24.4 & 0 \\
\hline
\end{tabular}

cannot remain constant in space and time. Therefore, spatial homogeneity involves horizontal and vertical mixing processes (Baltensperger et al., 1997b), and the amount of chemicals in such dynamic systems can be better described using their fluxes (Levich, 1963). A number of studies have used the fluxes to assess the transport and cycling of both natural and anthropogenic chemicals in the environment. Tani et al. (2002) investigated the diurnal and seasonal variations of monoterpene emission above a Japanese red pine forest using fluxes. The study shows that the atmospheric fluxes of chemicals are affected by micrometeorological parameters such as relative humidity, global radiation. Karl and Guenther (2004) explored how the variance of biogenic VOC emission and degradation relate to their fluxes and lifetime in the atmosphere. The study shows that the fast monitoring capabilities of the PTR-MS system could be used for assessing the magnitude of biogenic VOCs and homogeneity of fluxes and for characterization of atmospheric VOC lifetimes in remote places. According to Dämmgen et al. (1997) description and modelling of fluxes within natural systems are key elements for the description of ecosystems. Fluxes can be easily obtained by calculation from the velocity of the flowing medium and partial density of the entity (Eq. 2).
The fluxes of individual hydrocarbons detected in all air samples during the selected time periods (calculated using Eq. 2) are given in Fig. 3. The diagrams of the initial fluxes $\left(J_{c}\right)$ show the highest values of the following hydrocarbons (in $\mu \mathrm{g} \cdot \mathrm{m}^{-2} \mathrm{~s}^{-1}$ ) on 11 (12) March: benzene 14.3 (4.38), 1,3,5-trimethylbenzene 5.27 (1.79), toluene 4.40 (1.56), ibutane 7.87 (7.27), i-pentane 3.61 (3.40), and n-butane 3.23 (2.80). Insignificant concentrations (approximately $10 \%$ of the benzene concentration) of the following hydrocarbons were found in the ambient air on the same dates: 1,2,4trimethylbenzene $1.49(0.51), \mathrm{m} / \mathrm{p}$-xylene 1.09 (0.28), oxylene 1.02 (0.24), ethylbenzene 0.83 (0.45). OH-rate constants of these compounds are higher than for benzene and consequently the atmospheric lifetimes in winter for these chemicals (16.8 h, 23.5 h, 40.6 h, and 3.2 days, respectively) are shorter than for benzene (19.9 days) (see Table 2). The final flux values $\left(J_{c}{ }^{\prime}\right)$ for all hydrocarbons on 24 February and 1 March were lower than the initial flux values on 11 and 12 March. The high concentrations of alkanes in ambient air could be due to their long persistence in the atmosphere, with distant sources making a greater contribution to their concentrations than in the case of the faster reacting VOCs (Hellén et al., 2006). 
Table 2. Physico-chemical parameters of VOCs, measured in air samples during CLACE 5.

\begin{tabular}{llllllll}
\hline Compound & $\begin{array}{l}\text { Molecular } \\
\text { weight }\end{array}$ & $\begin{array}{l}\text { Water solubility } \\
(\mathrm{mg} / \mathrm{L})\end{array}$ & $\begin{array}{l}\mathrm{H}\left(25^{\circ} \mathrm{C}\right) \\
\left(\mathrm{kPam}^{3} / \mathrm{mole}\right)\end{array}$ & $\begin{array}{l}\mathrm{H}\left(25^{\circ} \mathrm{C}\right) \\
(\text { dimensionless })\end{array}$ & $\begin{array}{l}\text { Boiling } \\
\text { point }\left({ }^{\circ} \mathrm{C}\right)\end{array}$ & $\begin{array}{l}\text { OH Rate }^{\mathrm{a}} \\
\text { constant } \\
\left(\mathrm{cm}^{3} / \mathrm{molecule.s}\right)\end{array}$ & $\begin{array}{l}\text { Atmospheric } \\
\text { lifetime }^{\mathrm{a}}\end{array}$ \\
\hline Isobutane & 58 & 48.8 & 120.6 & 47.6 & -11.7 & $1.97 \times 10^{-12}$ & 11.7 days \\
n-butane & 58 & 61.2 & 96.3 & 38 & -0.5 & $2.14 \times 10^{-12}$ & 10.8 days \\
isobutene & 56 & 263 & 22.1 & 8.27 & -6.9 & $5.14 \times 10^{-11}$ & $10.8 \mathrm{~h}$ \\
3 methylpentane & 86 & 17.9 & 170.2 & 67.2 & 63.2 & $5.7 \times 10^{-12}$ & 4 days \\
2 methylpentane & 86 & 14 & 173.3 & 68.4 & 60.2 & $5.6 \times 10^{-12}$ & 4.1 days \\
n-pentane & 72 & 38 & 126.7 & 50 & 36 & $3.54 \times 10^{-12}$ & 6.5 days \\
isopentane & 72 & 48 & 141.9 & 56 & 27.8 & $3.36 \times 10^{-12}$ & 6.8 days \\
n-hexane & 86 & 9.5 & 182.4 & 72 & 68.7 & $5.09 \times 10^{-12}$ & 4.5 days \\
benzene & 78 & 1780 & 0.557 & 0.22 & 80.1 & $1.16 \times 10^{-12}$ & 19.9 days \\
toluene & 92 & 526 & 0.673 & 0.27 & 110.6 & $5.64 \times 10^{-12}$ & 4.1 days \\
o-xylene & 106 & 178 & 0.525 & 0.21 & 144.4 & $1.37 \times 10^{-11}$ & $40.6 \mathrm{~h}$ \\
m/p-xylene & 106 & 161 & 0.728 & 0.29 & 139.1 & $2.36 \times 10^{-11}$ & $23.5 \mathrm{~h}$ \\
ethylbenzene & 106 & 169 & 0.798 & 0.32 & 136.2 & $7.1 \times 10^{-12}$ & 3.2 days \\
1,3,5-TMB & 120 & 48 & 0.889 & 0.36 & 165 & $5.75 \times 10^{-11}$ & $9.6 \mathrm{~h}$ \\
1,2,4-TMB & 120 & 57 & 0.624 & 0.25 & 169 & $3.3 \times 10^{-11}$ & $16.8 \mathrm{~h}$ \\
\hline
\end{tabular}

a Assuming $[\mathrm{OH}]=5.10^{5}$ molecules. $\mathrm{cm}^{-3}$ the upper limit of the $\mathrm{OH}$ concentrations in the winter-free troposphere (Li et al., 2005)

Most heterogeneous transformation processes in liquids and gases (e.g. solution, adsorption and desorption) depend considerably on hydrodynamic factors (Levich, 1963). Li et al. (2009) evaluated the main processes contributing to the air-water exchange of SOCs (semivolatile organic compounds) such as diffusive vapour exchange, precipitation scavenging of vapours and particle-sorbed chemicals (wet deposition), and dry deposition with particles, whereas the deposition fluxes were used for the quantitative description of precipitation scavenging.

Figure 1 shows that the difference between the initial flux $\left(J_{c}\right)$ before wet deposition and the final flux $\left(J_{c}{ }^{\prime}\right)$ after wet deposition is equivalent to the wet deposition flux $\left(J_{d}\right)$. Therefore, the efficiency of VOC scavenging $(E)$ by snow was calculated from their concentrations as well as from fluxes in the air and was defined as difference between the initial and final concentration/flux values of compounds before and after wet deposition:

$E=\frac{C-C^{\prime}}{C} \cdot 100 \%=\frac{J_{c}-J_{c}^{\prime}}{J_{c}} \cdot 100 \%$

The efficiency of removal of VOCs by snow events during CLACE 5 calculated by Eq. (5) is shown in Table 3 and in Fig. 4. The efficiency of scavenging of individual compounds from the atmosphere varied widely (range $30-100 \%$ ). A possible explanation for this wide range has been proposed by Crutzen et al. (2000). The organic compounds are removed to varying degrees from the atmosphere by precipitation depending on their reactivity in hydrometeors. Hence, the quantitative characteristics of the distribution of the investigated hydrocarbons between the air and snow phases in the atmosphere should be different as well. The removal efficiency values, calculated from concentration of hydrocarbons are similar to the efficiency values, calculated from compound fluxes (see Table 3 and Fig. 4).

According to Suzuki (1994) the fluxes of chemicals are controlled by precipitation rates rather than their atmospheric concentrations. Therefore, for the description of scavenging efficiencies of VOCs efficiency values calculated from fluxes are preferentially used.

The ranking of organic compounds according to their removal efficiency indicates a low dependency on their solubility in water (see Table 2). Thus isopentane and n-pentane, with very high values of Henry's law constants (50 and 56, respectively), were removed from the atmosphere by snow 
Table 3. Initial $(C)$ concentration before wet deposition and the final $\left(\mathrm{C}^{\prime}\right)$ concentration after wet deposition of VOCs in the ambient air and their removal efficiency $\left(\mathrm{E}_{c}\right)$ by snow, calculated from air concentrations during CLACE 5 (2006).

\begin{tabular}{|c|c|c|c|c|c|c|}
\hline \multirow[t]{2}{*}{ Sampling time } & \multicolumn{3}{|c|}{24 Feb 200611 Mar 2006 16:00-20:00 } & \multicolumn{3}{|c|}{1 Mar 200612 Mar 2006 08:00-12:00 } \\
\hline & $\mathrm{C}^{\prime}\left[\mu \mathrm{g} \cdot \mathrm{m}^{-3}\right]$ & $\mathrm{C}\left[\mu \mathrm{g} \cdot \mathrm{m}^{-3}\right]$ & $\mathrm{E}_{C}(\%)$ & $\mathrm{C}^{\prime}\left[\mu \mathrm{g} \cdot \mathrm{m}^{-3}\right]$ & $\mathrm{C}\left[\mu \mathrm{g} \cdot \mathrm{m}^{-3}\right]$ & $\mathrm{E}_{C}(\%)$ \\
\hline Isobutane & 0.360 & 0.605 & 41 & 0.319 & 1.085 & 71 \\
\hline n-butane & 0.106 & 0.265 & 60 & 0.128 & 0.418 & 69 \\
\hline isobutene & 0.163 & 0.206 & 21 & 0.087 & 0.224 & 61 \\
\hline 3 methylpentane & 0.201 & 0.304 & 34 & 0.092 & 0.188 & 51 \\
\hline 2 methylpentane & 0.122 & 0.205 & 40 & 0.074 & 0.168 & 56 \\
\hline n-pentane & 0.112 & 0.278 & 60 & 0.039 & 0.234 & 83 \\
\hline isopentane & 0.105 & 0.249 & 58 & 0.036 & 0.507 & 93 \\
\hline n-hexane & 0.065 & 0.158 & 59 & 0.052 & 0.218 & 76 \\
\hline benzene & 0.433 & 1.101 & 61 & 0.111 & 0.654 & 83 \\
\hline toluene & 0.177 & 0.339 & 48 & 0.064 & 0.233 & 73 \\
\hline o-xylene & 0.055 & 0.079 & 30 & 0.022 & 0.036 & 39 \\
\hline $\mathrm{m} / \mathrm{p}$-xylene & 0.057 & 0.084 & 32 & 0.020 & 0.041 & 51 \\
\hline ethylbenzene & 0.045 & 0.064 & 30 & 0.021 & 0.067 & 68 \\
\hline 1,3,5-TMB & 0.179 & 0.405 & 56 & 0.075 & 0.266 & 72 \\
\hline $1,2,4-\mathrm{TMB}$ & 0.045 & 0.115 & 61 & 0.019 & 0.077 & 75 \\
\hline
\end{tabular}

Table 4. Concentrations of VOCs in air $\left(C_{\text {air }}\right)$ and snow $\left(C_{\text {snow }}\right)$ samples collected on 24 February and 1 March 2006 , and distribution coefficients derived empirically $\left(K_{\text {air/snow }}\right)$ and calculated from previous reports $\left(K_{\text {air/snow }}^{\mathrm{b}}\right)$.

\begin{tabular}{|c|c|c|c|c|c|c|c|}
\hline Sampling time & & Feb 2006 12:45 & & & Mar 2006 14:50 & & \\
\hline \multirow[t]{2}{*}{ Ambient temperature } & \multicolumn{3}{|c|}{$T=-13.7^{\circ} \mathrm{C}(259.3 \mathrm{~K})$} & \multicolumn{3}{|c|}{$T=-24^{\circ} \mathrm{C}(249 \mathrm{~K})$} & \multirow[b]{2}{*}{$K_{\mathrm{air} / \mathrm{snow}}^{\mathrm{b}}$} \\
\hline & $C_{\text {air }}\left[\mu \mathrm{g} \mathrm{m}^{-3}\right]$ & $C_{\text {snow }}^{\mathrm{a}}\left[\mathrm{ng} \mathrm{L}^{-1}\right]$ & $K_{\text {air/snow }}$ & $C_{\text {air }}\left[\mu \mathrm{g} \mathrm{m}^{-3}\right]$ & $C_{\text {snow }}^{\mathrm{a}}\left[\mathrm{ng} \mathrm{L}^{-1}\right]$ & $K_{\text {air/snow }}$ & \\
\hline benzene & 0.37 & 69 & 0.0054 & 0.33 & 69 & 0.0048 & 0.0062 \\
\hline toluene & 0.15 & 397 & 0.0004 & 0.19 & 558 & 0.0003 & 0.0028 \\
\hline o-xylene & 0.05 & 166 & 0.0003 & 0.07 & 238 & 0.0003 & 0.0011 \\
\hline $\mathrm{m} / \mathrm{p}$-xylene & 0.04 & 104 & 0.0004 & 0.06 & 169 & 0.0004 & 0.0013 \\
\hline ethylbenzene & 0.04 & 172 & 0.0002 & 0.06 & 285 & 0.0002 & 0.0015 \\
\hline 1,3,5-TMB & 0.15 & 42 & 0.0036 & 0.23 & 68 & 0.0034 & 0.0052 \\
\hline 1,2,4-ТМВ & 0.04 & 203 & 0.0002 & 0.06 & 477 & 0.0001 & 0.0005 \\
\hline
\end{tabular}

${ }^{a}$ Fries et al. (2008) ${ }^{\text {b }}$ Calculated using Eq. (4) by Lei and Wania (2004), and Eq. (5) by Roth et al. (2004), extrapolated to -13.7 ${ }^{\circ}$

very effectively (60-90\%). In contrast, o-xylene (Henry's constant $=0.21$ ) was removed with low efficiency $(35-37 \%)$. The reason for these results could be that dissolution is not the major mechanism of uptake of VOCs by snow. The effi- ciency of snow removal of aromatic hydrocarbons was temperature dependent; the lower the ambient temperature at Jungfraujoch, the greater was the efficiency of washing out. 
Thus, the highest removal efficiency values for all compounds were obtained at an ambient temperature of approximately $-24^{\circ} \mathrm{C}$. An increase in temperature to $-13.7^{\circ} \mathrm{C}$ decreased the removal efficiency by a factor of approximately two for some hydrocarbons including ethylbenzene and isobutene. At this temperature increase the removal efficiency for benzene, toluene, n-pentane and n-butane decreased by $20 \%$ on average (see Fig. 4). These findings validate the results of the uptake model of Fries et al. (2007) that revealed a higher uptake of aromatic hydrocarbons by ice crystals at lower temperatures.

According to Lei and Wania (2004), one possible explanation for this observation might be increasing removal of organic chemicals at low temperatures due to a reduction in vapor pressure together with decreasing temperature, which can influence the deposition mechanism and consequently air/ice partitioning. Other explanations could be that low temperatures (Hoff et al., 1995) or the large size and specific surface area of snow/ice crystals (Franz and Eisenreich, 1998,) promote snow/ice-hydrocarbon interactions. Specific snow surface area is a key parameter determining the capacity of snow for uptake of organic contaminants and is even higher during colder days (Burniston et al., 2007).

\subsection{Determination of distribution coefficients}

To estimate the distribution ratio of hydrocarbons between air and snow in the troposphere, their concentrations were determined in these phases during the CLACE 5 campaign. Air and snow samples were collected at the same time so that the measured concentrations reflected the equilibrium distribution. Unfortunately, alkanes could not be quantified in snow samples using the chosen analytical method. However, Gröllert and Puxbaum (2000) reported a maximum ratio of $130\left(\frac{C_{\text {snow }}}{C_{\text {ại }}}\right)$ for scavenging of alkanes by snow at an elevated alpine site.

Benzene, alkylated benzenes, chlorinated hydrocarbons and monoterpenes were quantified in snow samples, and benzene, toluene, m/p-xylene, o-xylene, ethylbenzene, 1,2,4trimethylbenzene and 1,3,5-trimethylbenzene were also quantified in the air samples (see Table 3). For these latter seven compounds, the distribution coefficients $\left(K_{\text {air/snow }}\right)$ were derived from measurements using Eq. (4) (Table 4). The distribution coefficients show a correlation with ambient temperature, with values of coefficients being higher for all compounds at $-13.7^{\circ} \mathrm{C}$ than at $-24^{\circ} \mathrm{C}$ (e.g. $5.3 \times 10^{-3}$ and $4.8 \times 10^{-3}$, respectively, for benzene). Unexpectedly, the highest distribution coefficient values were observed for benzene despite it having the highest water solubility $\left(1780 \mathrm{mgL}^{-1}\right)$ among the analyzed monoaromatic hydrocarbons. The lowest distribution coefficient value was found for 1,2,4-trimethylbenzene $\left(2 \times 10^{-4}\right)$, which has a water solubility of $57 \mathrm{mgL}^{-1}$. The distribution coefficients of the other aromatic hydrocarbons at $-13.7^{\circ} \mathrm{C}$ were $3.6 \times 10^{-4}$ for

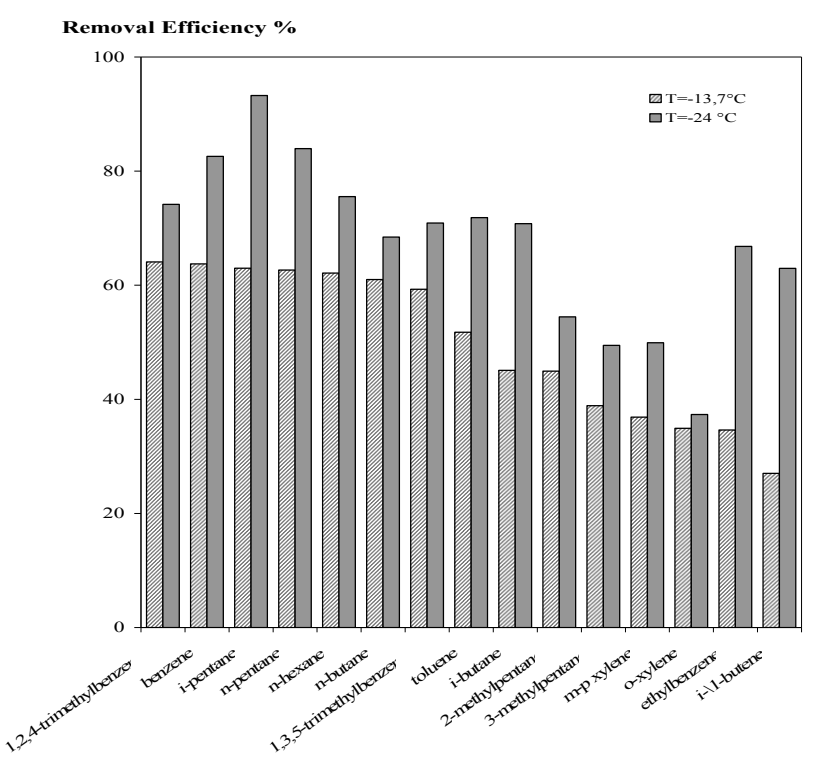

Fig. 4. Removal efficiency of VOCs by snow under various atmospheric conditions.

1,3,5-trimethylbenzene, $4 \times 10^{-4}$ for $\mathrm{m} / \mathrm{p}$-xylene, $4 \times 10^{-4}$ for toluene, $3 \times 10^{-4}$ for o-xylene, and $2.3 \times 10^{-4}$ for ethylbenzene.

Several studies have reported hydrophobic VOCs in precipitation at higher concentrations than predicted from Henry's law constants and ambient atmospheric concentrations (Sato et al., 2006; Fries et al., 2008).

Lei and Wania (2004) proposed Eq. (6) for estimating the distribution coefficients of a wide range of organic compounds at temperatures below $0^{\circ} \mathrm{C}$.

$K_{\mathrm{air} / \mathrm{snow}}^{b}=\frac{1}{A_{I} \cdot \rho_{W} \cdot K_{S A}}$

where $A_{I}$ is the specific surface area in $\mathrm{m}^{2} \mathrm{~g}^{-1}$ and $\rho_{w}$ is the density of ice $\left(\mathrm{g} \mathrm{m}^{-3}\right)$.

$K_{S A}$ is the sorption coefficient onto the snow surface $\left(\mathrm{m}^{3}\right.$ $\mathrm{m}^{-2}$ ), determined for a wide range of hydrophobic and hydrophilic organic substances at $-6.8^{\circ} \mathrm{C}$ (Roth et al., 2004).

The $K_{S A}$ values have been extrapolated to a temperature of $-13.7^{\circ} \mathrm{C}$ for the compounds considered in the present study.

The distribution coefficients determined empirically and theoretically show the same pattern as described above (see Table 4). Comparison of the distribution coefficients derived from measurements during CLACE 5 ( $\left.K_{\text {air/snow }}\right)$ with those values $\left(K_{\text {air/snow }}^{b}\right)$ calculated using Eq. (6) shows good consistency for benzene $\left(5.3 \times 10^{-3}\right.$ and $6.2 \times 10^{-3}$, respectively $)$ and 1,3,5-trimethylbenzene $\left(3.6 \times 10^{-3}\right.$ and $5.2 \times 10^{-3}$, respectively) (see Table 4). The small difference in coefficient values for these compounds indicates that their sorption onto the snow surface plays a significant role in their removal 
by snow. For 1,2,4-trimethylbenzene, o-xylene, m/p-xylene, ethylbenzene and toluene the calculated coefficient values were $0.5 \times 10^{-3}, 1.1 \times 10^{-3}, 1.3 \times 10^{-3}, 1.5 \times 10^{-3}$ and $2.8 \times 10^{-3}$, respectively (Table 4 ). However, for these aromatic hydrocarbons the distribution coefficients calculated theoretically were one order of magnitude higher than the empirical values (see Table 4). On one hand calculated coefficients can differ from the empirical coefficients, because a specific snow surface area in Eq. (6) may largely differ from that of the snowflakes during snowfall. On the other hand, according to Roth (2004) there is, however, the evidence that experimental sorption data cannot always be described solely by physical adsorption. It also indicates that a combination of processes like dissolution in the bulk ice or in a surface layer, incorporation of gases into the crystal lattice during crystal growth, particle scavenging (nucleation and impaction scavenging by growing ice crystals) (Fries et al., 2008) might contribute to the overall sorption on ice. For the theoretical understanding of the various sorption processes in and on snow, additional laboratory investigations should be conducted.

\section{Conclusions}

VOC concentrations were measured in air and snow samples during CLACE 5 in the winter of 2006. The fluxes of individual organic compounds were determined under various atmospheric conditions, and from the concentrations and fluxes the removal efficiency of the hydrocarbons by snow was calculated. The efficiency values of some investigated compounds (e.g. alkanes, m/p-xylene, and o-xylene) were independent from their water solubility and volatility. The distribution coefficients between air and snow phases were derived for various aromatic hydrocarbons from measurements made during the present study, and from calculated values obtained from previous studies. The empirical and calculated air/ice distribution coefficients showed the same pattern, but the empirical coefficients for several hydrocarbons were one order of magnitude lower than the calculated values. For compounds with low water solubility and a low distribution coefficient, removal from the air by snow cannot be described only by physical adsorption. For these compounds in particular, other processes such as particle scavenging should also be considered. The measured distribution coefficients and the removal efficiencies showed a correlation with temperature, characterized by increased VOC removal by snow with decreasing ambient temperature.

Acknowledgements. Financial support from the Deutsche Forschungsgemeinschaft for project B8 in the frame of SFB 641 (The Tropospheric Ice Phase) is gratefully acknowledged. We acknowledge the International Foundation High Altitude Research stations Jungfraujoch and Gornergrat (HFSJG), MeteoSwiss for making our research possible at Jungfraujoch. We thank Urs Baltensperger, Ernest Weingartner, and Joachim Curtius for organizing the field campaigns. Finally we also thank the custodians at JFJ, the Fischers and the Hemunds, for their patience and enthusiasm in supporting our research activities.

Edited by: M. Ammann

\section{References}

Atkinson, R., Baulch, D. L., Cox, R. A., Crowley, J. N., Hampson, R. F., Hynes, R. G., Jenkin, M. E., Rossi, M. J., Troe, J., and IUPAC Subcommittee: Evaluated kinetic and photochemical data for atmospheric chemistry: Volume II - gas phase reactions of organic species, Atmos. Chem. Phys., 6, 3625-4055, 2006, http://www.atmos-chem-phys.net/6/3625/2006/.

Baltensperger, U., Gäggeler, H. W., Jost, D. T., Lugauer, M., Schwikowski, M., Weingartner, E., and Seibert, P.: Aerosol climatology at the high-Alpine site Jungfraujoch, Switzerland, J. Geophys. Res., 102(D16), 19707-19715, 1997a.

Baltensperger, U., Schwikowski, M., Jost, D. T., Nyeki, S., Gäggeler, H. W., and Poulida, O.: Scavenging of atmospheric constituents in mixed phase clouds at the high-alpine site Jungfraujoch part I: Basic concept and aerosol scavenging by clouds, Atmos. Environ., 32, 3975-3983, 1997b.

Bidleman, T. F.: Atmospheric processes, Environ. Sci. Technol., 22, 361-367, 2001.

Burniston, D. A., Strachan, W. J. M., Hoff, J. T., and Wania, F.: Changes in surface area and concentrations of semivolatile organic contaminants in aging snow, Environ. Sci. Technol., 41, 4932-4937, 2007.

Crutzen, P. J. and Lawrence, M. G.: The impact of precipitation scavenging on the transport of trace gases: A 3-dimensional model sensitivity study, J. Atmos. Chem., 37, 81-112, 2000.

Dämmgen, U., Grünhage, L., and Jäger, H.-J.: Description, assessment and meaning of vertical fluxes of matter within ecotopes: a systematic consideration, Environ. Pollut., 96, 249-260, 1997.

Dollard, G. J., Dumitrean, P., Telling, S., Dixon, J., and Derwent, R. G.: Observed trends in ambient concentrations of C2-C8 hydrocarbons in the United Kingdom over the period from 1993 to 2004, Atmos. Environ., 41, 2559-2569, 2007.

Forrer, J., Rüttimann, R., Schneiter, D., Fischer, A., Buchmann, B., and Hofer, P.: Variability of trace gases at the high Alpine site Jungfraujoch caused by meteorological transport processes, J. Geophys. Res., 105, D10, 12241-12251, 2000

Fries, E., Starokozhev, E., Haunold, W., Jaeschke, W., Hoog, I., Mitra, S. K., and Borrmann, S.: Laboratory studies on the uptake of aromatic hydrocarbons by ice crystals during vapor depositional crystal growth, Atmos. Environ., 41, 6156-6166, 2007.

Fries, E., Sieg, K., Püttmann, W., Jaeschke, W., Winterhalter, R., Williams, J., and Moortgat, G.: Benzene, alkylated benzene, chlorinated hydrocarbons and monoterpenes in snow ice in spring at Jungfraujoch $\left(46.6^{\circ} \mathrm{N}, 8.0^{\circ} \mathrm{E}\right)$ during CLACE 4 and 5., Sci. Total Environ., 391, 269-277, 2008.

Franz, T. P. and Eisenreich, S. J.: Snow scavenging of polychlorinated biphenyls and polycyclic aromatic hydrocarbons in Minnesota, Environ. Sci. Technol., 32, 1771-1778, 1998.

Fuzzi, S., Andreae, M. O., Huebert, B. J., Kulmala, M., Bond, T. C., Boy, M., Doherty, S. J., Guenther, A., Kanakidou, M., Kawamura, K., Kerminen, V.-M., Lohmann, U., Russell, L. M., and Pöschl, U.: Critical assessment of the current state of 
scientific knowledge, terminology, and research needs concerning the role of organic aerosols in the atmosphere, climate, and global change, Atmos. Chem. Phys., 6, 2017-2038, 2006, http://www.atmos-chem-phys.net/6/2017/2006/.

Goss, K.-U.: The air/surface adsorption equilibrium of organic compounds under ambient conditions. Critical reviews, Environ. Sci. Technol., 34, 339-389, 2004.

Gröllert, C. and Puxbaum, H.: Lipid organic aerosol and snow composition at an elevated alpine site in the fall and spring season and scavenging ratios for single compounds, Water Air Soil Poll., 117, 157-173, 2000.

Hellén, H., Hakola, H., Pirjola, L., Laurila, T., and Pystynen, K.-H.: Ambient air concentrations, source profiles, and source apportionment of 71 different $\mathrm{C} 2-\mathrm{C} 10$ volatile organic compounds in urban and residential areas of Finland, Environ. Sci. Technol., 40, 103-108, 2006.

Hoff, J. T., Wania, F., Mackay, D., and Gillham, R.: Sorption of non-polar organic vapors by ice and snow, Environ. Sci. Technol., 29, 1982-1989, 1995.

Karl, T., Crutzen, P. J., Mandl, M., Staudinger, M., Guenther, A., Lordan, A., Fall, R., and Lindlinger, W.: Variability lifetime relationship of VOCs observed at the Sonnblick Observatory 1999 - Estimation of HO densities. Atmos. Environ., 35, 5287-5300, 2001.

Karl, T. and Guenther, A.: Atmospheric variability of biogenic VOCs in the surface layer measured by proton-transfer-reaction mass spectrometry, J. Mass Spectrom., 239, 77-86, 2004.

Kavouras, I. G., Mihalopoulos, N., and Stephanou, E. G.: Formation of atmospheric particles from organic acids produced by forests, Nature, 395, 683-686, 1998.

Kleindienst, T. E., Conver, T. S., McIver, C. D., and Edney, E. O.: Determination of secondary organic aerosol products from the photooxidation of toluene and their implication in ambient $\mathrm{PM}_{2.5}$, J. Atmos. Chem., 47, 79-100, 2004.

Lei, D. L and Wania, F.: Is rain or snow a more efficient scavenger of organic chemicals?, Atmos. Environ., 38, 3557-3571, 2004.

Levich, V.: Physicochemical Hydrodynamics, Amer. J. Physical, 31, 892-892, 1963.

Li, J., Cheng, H., Zhang, G., Qi, S., and Li, X.: Polycyclic aromatic hydrocarbon (PAH) deposition to and exchange at the air-water interface of Luhu, an urban lake in Guangzhou, China. Environ. Pollut., 157, 273-279, 2009.

Li, Y., Campana, M., Reimann, S., Schaub, D., Stemmler, K., Staehelin, J., and Peter, T.: Hydrocarbon concentrations at the Alpine mountain sites Jungfraujoch and Arosa, Atmos. Environ., 39, 1113-1127, 2005.

Monod, A., Sive, B. C., Avino, P., Chen, T., Blake, D. R., and Rowland, F. S.: Monoratomatic compounds in ambient air of various cities: a focus on correlations between the xylenes and ethylbenzene, Atmos. Environ., 35, 135-149, 2001.
National Research Council: Rethinking the Ozone Problem in Urban and Regional Air Pollution. National Academy Press, Washington, DC, 1991.

Odum, J. R., Jungkamp, T. P. W., Griffin, R. J., Forstner, H. J. L., Flagan, R. C., and Seinfeld, J. H.: Aromatics, reformulated gasoline, and atmospheric organic aerosol formation, Environ. Sci. Technol., 31, 1890-1897, 1997.

Prévot, A. S. H., Dommen, J., and Bäumle, M.: Influence of road traffic on volatile organic compound concentrations in and above a deep Alpine valley, Atmos. Environ., 34, 4719-4726, 2000.

Roth, C. M., Goss, K.-U., and Schwarzenbach, R. P.: Sorption of diverse organic vapours to snow, Environ. Sci. Technol., 38, 40784084, 2004.

Sato, E., Matsumoto, K., Okochi, H., and Igawa, M.: Scavenging effect of precipitation on volatile organic compounds in ambient atmosphere, B. Chem. Soc. Jpn., 79, 1231-1233, 2006.

Sieg, K., Fries, E., and Püttmann, W.: Analysis of BTEX and naldehydes C6-C10 in melted snow water by use of solid phase dynamic extraction (SPDE) combined with GC/MS, J. Chromatogr. A, 1178, 178-186, 2008.

Suzuki T.: Relationship between atmospheric fluxes and concentrations of terrigenous materials in the surface air over the Japan sea, J. Oceanogr., 50, 173-178, 1994.

Wania, F., Mackay, D. and Hoff, J. T.: The importance of snow scavenging of polychlorinated biphenyl and polycyclic aromatic hydrocarbon vapors, Environ. Sci. Technol., 33, 195-197, 1999.

Winkler, J., Blank, P., Glaser, K., Gomes, J. A. G., Habram, M, Jambert, C., Jaeschke, W., Konrad, S., Kurtenbach, R., Lenschow, P., Lörzer, J. C., Perros, P. E., Pesch, M., Prümke, H. J., Rappenglück, B., Schmitz, Th., Slemr, F., Volz-Thomas A., and Wickert, B.: Ground-based and airborne measurements of nonmethane hydrocarbons in BERLIOZ: Analysis and selected results, J. Atmos. Chem., 42, 465-492, 2002.

Tani, A., Nozoe, S., Aoki, M., and Hewiit, C. N.: Monoterpene fluxes measured above a Japanese red pine forest at Oshiba plateau, Japan, Atmos. Environ., 36, 3391-3402, 2002.

Zalel, A., Yuval, and Broday, D. M.: Revealing source signatures in ambient BTEX concentrations, Eniviron. Pollut., 156, 553-562, 2008.

Zanis, P., Monks, P. S., Schuepbach E., and Penkett, S. A.: The role of in-situ photochemistry in the control of ozone during spring at the Jungfraujoch observatory $(3.580 \mathrm{~m}$ a.s.1.)-comparison of model results with measurements, J. Atmos. Chem., 37(1), 1-27, 2000. 